\title{
Sternotherus depressus Tinkle and Webb 1955 - Flattened Musk Turtle
}

\author{
C. Kenneth Dodd, JR. ${ }^{1}$ \\ ${ }^{1}$ Department of Wildlife Ecology and Conservation, University of Florida, \\ Gainesville, Florida 32611 USA [Terrapene600@gmail.com]
}

\begin{abstract}
Summary.-Sternotherus depressus (Family Kinosternidae) is a crevice-adapted species endemic to clear, clean streams and rivers of the upper Warrior River Basin, north-central Alabama. It is threatened by habitat alteration and degradation, disease, and possibly by collecting. The turtle is protected by United States federal and Alabama state law. Conservation measures should include research on life history, habitat use, demography, genetics of fragmented populations, and the effects of disease (if still present) on both individual turtles and affected populations. Historical locations, especially important sites sampled from 1981 to 2003 , should be re-sampled and designated permanent monitoring sites. Local efforts to restore stream quality in the Warrior River Basin need to be undertaken, adjacent riparian habitats must be protected, laws and regulations should be enforced, and government agencies and non-governmental organizations should promote an understanding of the importance of biodiversity and endangered species management to residents and county officials.

Distribution. - USA. Restricted to the upper Warrior River Basin, north-central Alabama.

Synonymy.-Sternotherusdepressus Tinkle and Webb 1955,Sternothaerusdepressus, Sternotherus minor depressus, Kinosternon depressum.

SubSPECIES. - None recognized.

STATUS. - IUCN 2007 Red List: Vulnerable (VU B1+2c) (assessed 1996, needs updating); CITES: Not Listed; US ESA: Threatened.
\end{abstract}

Taxonomy. - The flattened musk turtle was described by Tinkle and Webb (1955). Since then, there has been much discussion of the turtle's taxonomic status (e.g., Wermuth and Mertens 1961; Estridge 1970; Mount 1975; Ernst et al. 1989; Walker et al. 1998). Specific status is warranted based on morphological (Ernst et al. 1989) and biochemical data (Seidel and Lucchino 1981; Walker and Avise 1998; Walker et al. 1998). Turtles in several western tributaries of the Warrior system (e.g., North River and Blue Creek, Tuscaloosa and Fayette counties) and at least one eastern tributary of the Sipsey River (Boxes Creek) of the Tombigbee River drainage appear to be intermediate between S. depressus and S. minor based on shell shape and head and neck patterns. Ernst et al. (1989) generally referred intermediate populations to $S$. depressus, although they did not discuss the Boxes Creek turtles. Iverson (1977a, b) suggested that

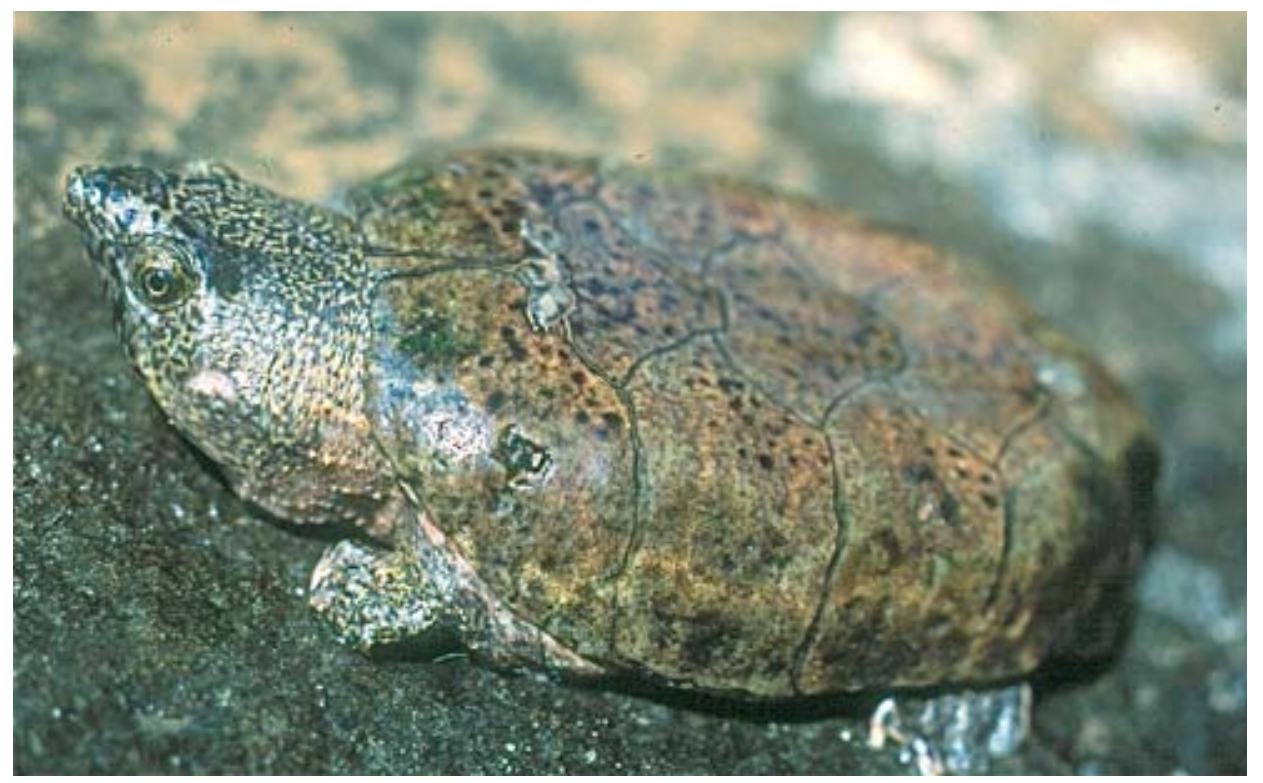

Figure 1. Old adult Sternotherus depressus from Gurley Creek, Alabama. Photo by C. Kenneth Dodd, Jr. 


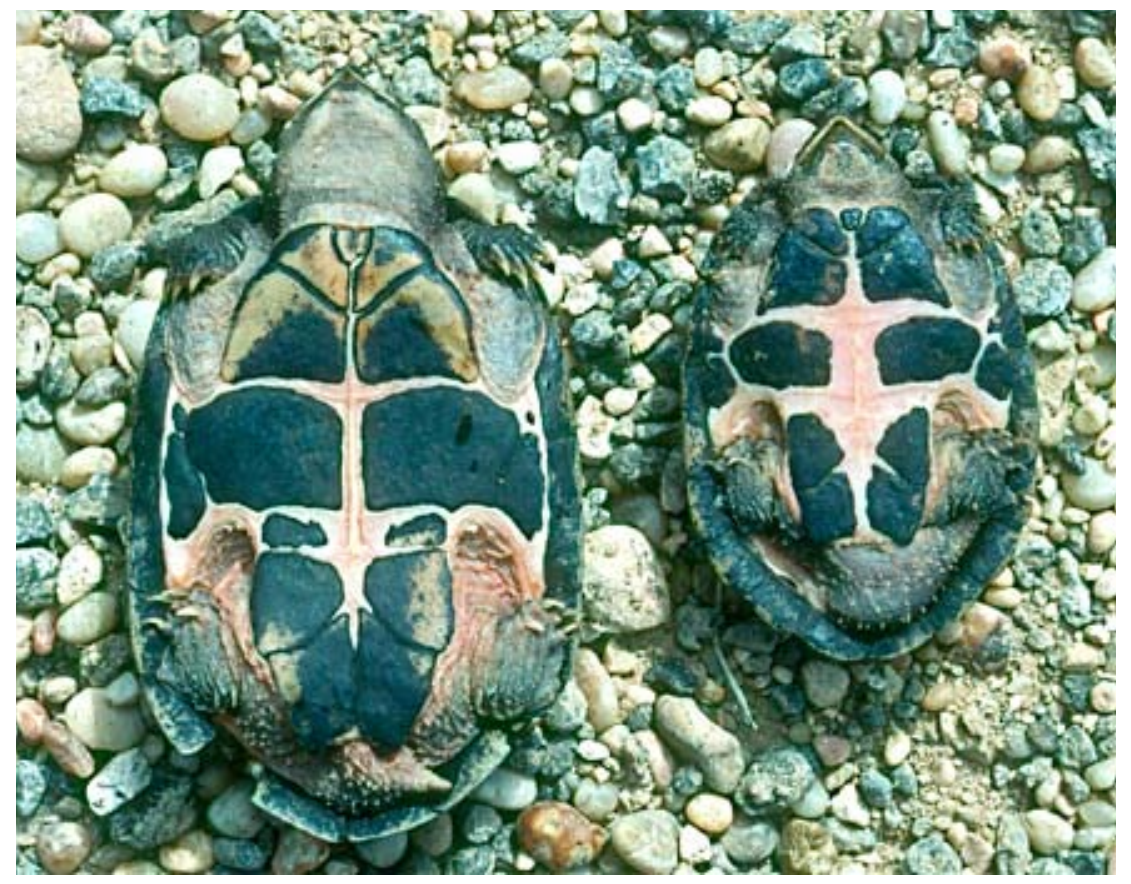

Figure 2. Adult Sternotherus depressus from Lost Creek, Alabama. Left: female. Right: male. Photo by C. Kenneth Dodd, Jr.

hybridization resulted from secondary contact after the construction of impoundments at the Fall Line eliminated natural geographic barriers to dispersal.

The flattened musk turtle is phylogenetically closest to the Sternotherus odoratus / S. carinatus clade, based on molecular (Walker and Avise 1998; Walker et al. 1998) as well as morphological and ecological considerations (Tinkle and Webb 1955; Tinkle 1958, 1962;). Previous suggestions that $S$. carinatus was not closely related to $S$. depressus (Seidel and Lucchino 1981; Seidel et al. 1981) have not been substantiated. No subspecies are recognized, although turtles from different stream drainages vary phenotypically.

Seidel et al. (1986) synonymized Sternotherus with Kinosternon based on biochemical and karyological evidence; thus, some references may refer to flattened musk turtles as Kinosternon depressum (Ernst et al.1989; Ernst and Barbour 1989; Iverson 1992; Bonin et al. 2006). This arrangement

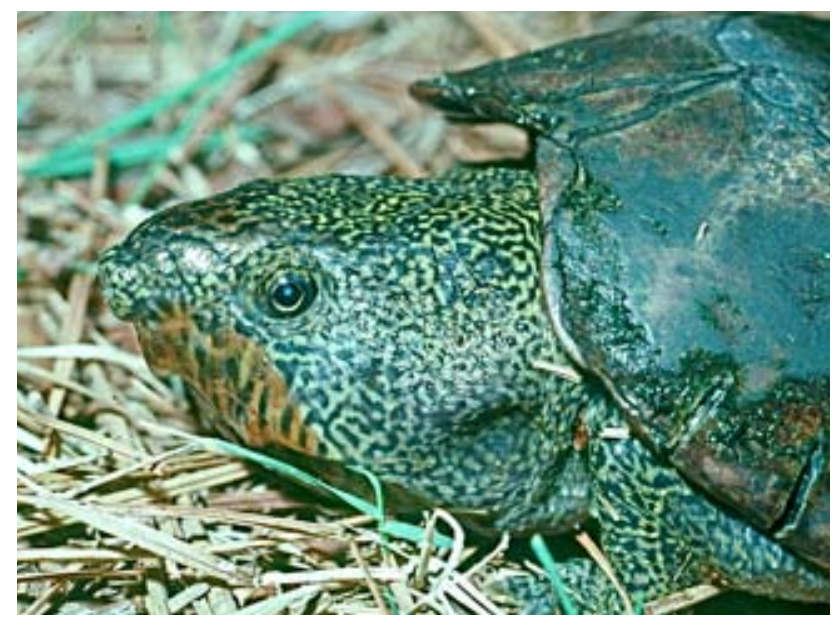

Figure 4. Old adult Sternotherus depressus from Sipsey Fork, Alabama. Photo by C. Kenneth Dodd, Jr. has not been followed by most turtle researchers (Ernst et al. 1994; Fritz and Havaš 2007).

Description. - Sternotherus depressus is a small, dark, mostly brown, turtle-adults measure approximately 65-120 mm in carapace length (CL), depending on sex, with males attaining maturity on average at a slightly smaller size than females (Close 1982). Hatchlings measure 31-33 mm

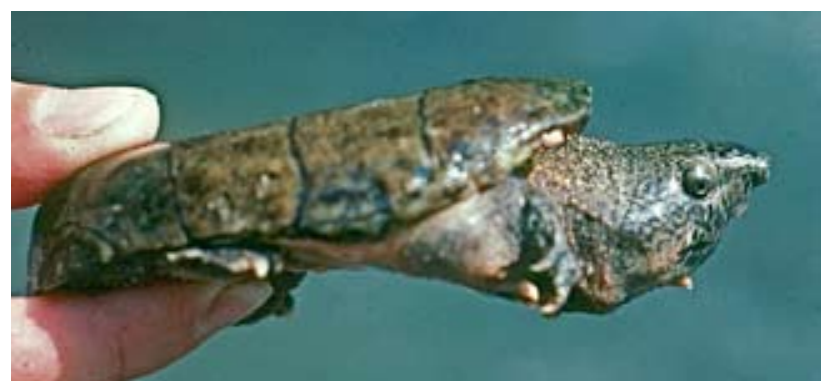

Figure 4. Old adult Sternotherus depressus from Gurley Creek, Alabama, with very flat shell. Photo by C. Kenneth Dodd, Jr.

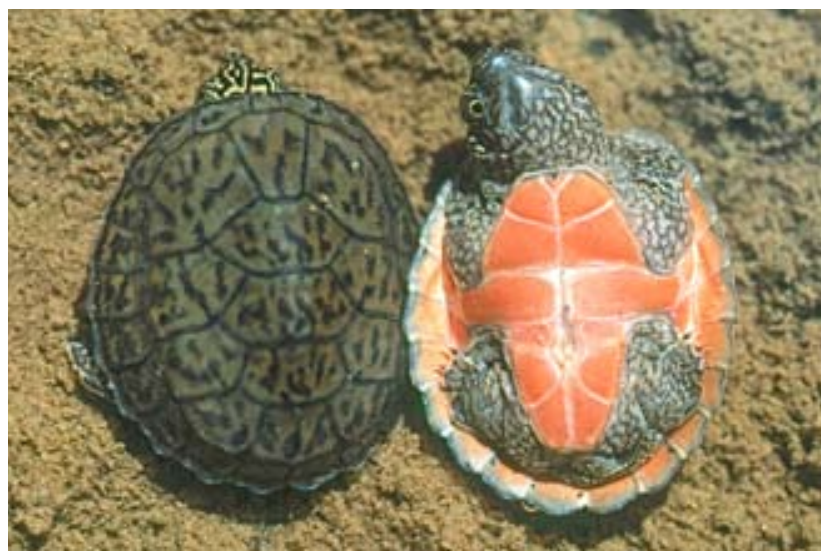

Figure 5. Hatchling Sternotherus depressus from Alabama. Photo by C. Kenneth Dodd, Jr. 


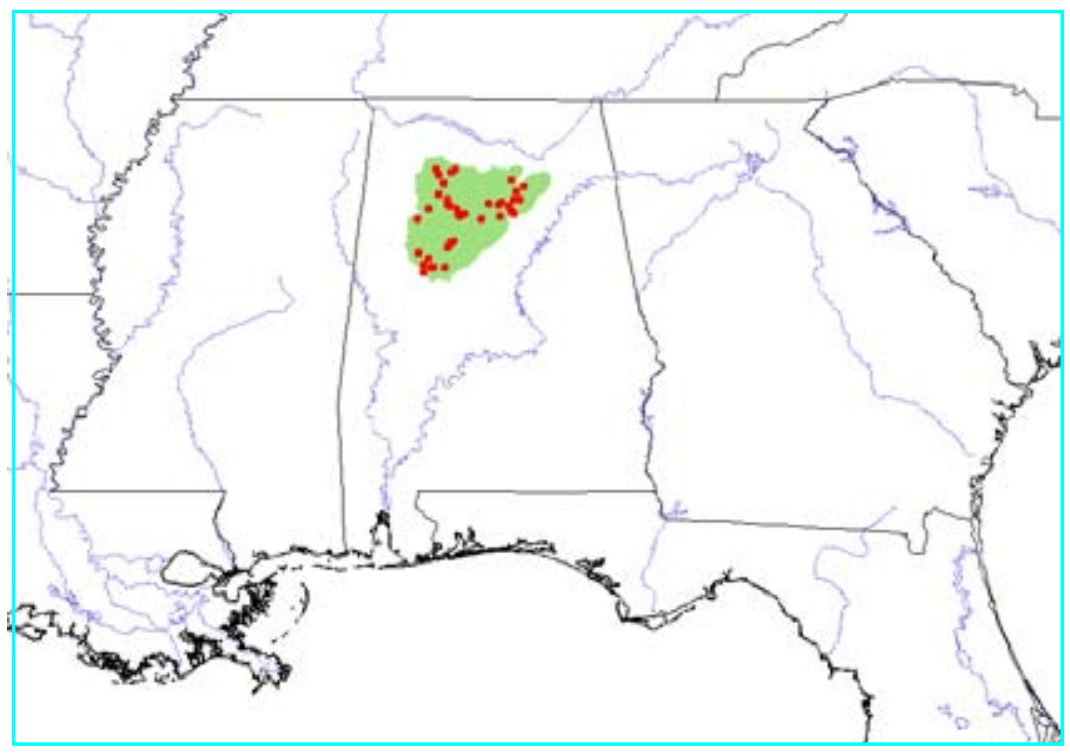

Figure 6. Distribution of Sternotherus depressus in Alabama, USA. Red points = museum and literature occurrence records based on published records plus more recent and author's data; green shading = projected distribution based on GIS-defined hydrologic unit compartments (HUCs) constructed around verified localities and then adding HUCs that connect known point localities in the same watershed or physiographic region, and similar habitats and elevations as verified HUCs (Buhlmann et al., unpubl. data), and adjusted based on author's data.

CL (Dodd et al. 1988) with a pronounced dorso-ventrally flattened shell (Tinkle and Webb 1955; Dodd et al. 1988; Ernst et al. 1989). Adult males are slightly smaller (mean $\mathrm{CL}=85.7 \mathrm{~mm}, \mathrm{n}=227$ ) than adult females (mean $\mathrm{CL}=$ $89.8 \mathrm{~mm}, \mathrm{n}=141$ ). There is no obvious sexual dimorphism except for tail length. Males have much longer and thicker tails than females, and the male's tail terminates in a pointed nail that is presumably used to anchor or stabilize his tail during copulation.

Shell color ranges from light brown to dark brown or olive, or even black. Dark striations may be present on carapacial scutes, especially on young animals. Keels are absent from the carapace of adults, although hatchlings and juveniles have a single keel which flattens as turtles become larger. The carapace may flare slightly, producing a shell widest at the posterior. Many carapaces have algal growths, especially at the seams between scutes. The plastron has no markings and in most populations is light yellowish to medium brown. However, some populations (e.g., Lost Creek) have individual turtles with black plastrons. Hatchlings have a light brown carapace with dark flecks; the plastron is pinkish-red but this color disappears as the turtle grows. A single xanthic individual has been reported (Marion et al. 1984).

The head and neck of S.depressus are greenish with dark reticulations that often break up to form spots on the top of the snout (Mount 1981). Stripes on the neck, if present, are narrow. The heads of some old individuals may be massive. In comparison with most S. minor, the flattened musk turtle is mild tempered.

According to Tinkle (1958), the skull of S. depresssus is low and similar in appearance to that of $S$. minor in that it lacks auxiliary ridges and excrescences. However, the slope of the skull from the anterior tip of the prefrontal to the posterior tip of the supraoccipital is horizontal. The skull contains a trench in the lower surface of the projecting portion of the supraoccipital which extends $75-100 \%$ of the length of the projection. The waist of the pterygoid is broad and the spinous process of the pterygoid is small. The parietal has no overthrust on its dorsal edge, and there are no prominent projections extending from the basioccipital. The position of carapacial scute seams have been used to ally $S$. depressus with the carinatus group (Tinkle 1962), although such a relationship is not supported by molecular data.

Distribution. - The flattened musk turtle is confined to larger streams - stream orders $>3$ (Dodd 1990) - of the Black Warrior River drainage above the Fall Line in northcentral Alabama (Tinkle 1959; Mount 1975, 1981; Iverson 1977a; Ernst et al. 1983, 1989, 1994; Rogers and Marion 2004a; Holmes 2005). The upstream distribution limits are unknown, but a number of small streams (for example, Borden and Caney creeks) in Bankhead National Forest that appear superficially to be good sites, do not have flattened musk turtles. Somewhat small streams (for example, Gurley Creek) may be inhabited if substantial snail populations are present. Similar-sized streams are not inhabited when mollusks are scarce. Turtles enter the upper reaches of large impoundments such as Lewis Smith Reservoir in northern Alabama, where they inhabit coves with good crevice habitat (Rogers and Marion 2004b; Holmes 2005). The turtle does not travel over land except to nest in riparian habitats within a few meters of streamside.

Habitat and Ecology. - The flattened musk turtle is principally a stream-dwelling turtle. Ideal habitat includes clean, clear streams and rivers with abundant cover sites under rocks and crevices in the fractured Pennsylvanian age sandstone of the Warrior Basin. The flattened shell is an adaptation to crevice occupation (Jackson 1988). The turtle also digs under logs and brush, or will bury into the sand and 


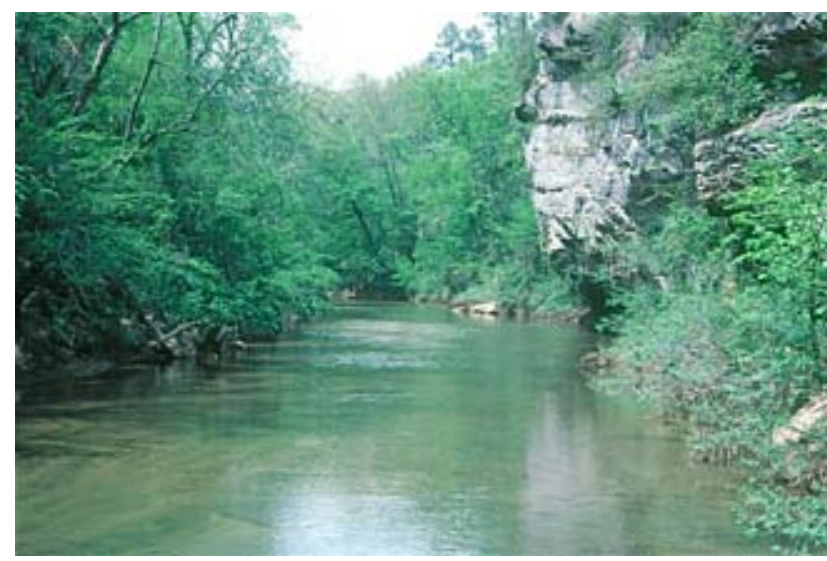

Figure 7. Sipsey Fork,Alabama.Location of the largest extant population of Sternotherus depressus. Photo by C. Kenneth Dodd, Jr.

mud along stream margins. Juveniles are found in shallow weed beds and riffles. Ideal habitat includes a water depth of approximately $0.5 \mathrm{~m}$, vegetated shallows alternating with deeper pools, pools containing detectablecurrent, an abundance of crevices, low silt loads and minimal silt deposits, abundant molluscanfauna, a relatively low nutrient content and bacterial count, moderate temperatures, and minimal pollution (Mount 1981; Johnson 1986; Dodd et al. 1988).

The flattened musk turtle is primarily a bottom foraging molluscivore feeding on gastropod snails and the introduced Asian clam, Corbicula manilensis (Marion et al.1991; Schnuelle 1997; Bailey and Guyer 1998). It also eats larval and adult insects. Johnson (1986) provided interesting observations of adult and juvenile feeding behavior. Turtles become active in mid-April and remain active until mid-October. Overwintering habits are unknown. In the early part of the season turtles are primarily diurnal, but they become more nocturnal or crepuscular as the water becomes warmer. However, turtles may be active at any time of day. Basking on branches, rocks, and logs has been reported (Mount 1981; Johnson 1986; Dodd et al. 1988), sometimes far above water. There is some question about the prevalence of basking in healthy turtles inasmuch as the majority of basking flattened musk turtles captured have been affected by disease (Mount 1981; Dodd 1988b, 1990).

Males reach sexual maturity at 4-6 yrs and females reach maturity at 6-8 yrs (Close 1982). Females reach maximum size at 30-40 yrs, and males at 50-60 yrs (Holmes 2005). Females produce an average of two clutches of 1-3 eggs annually which are deposited on sandy slopes adjacent to the stream. The eggs are approximately $32 \mathrm{~mm} \times 16 \mathrm{~mm}$, and weigh $5.5 \mathrm{~g}$. Nesting occurs generally from May through late July, with hatching through at least mid-September. Population structure and size, biomass, and sex ratios may or may not vary among drainages (Dodd et al. 1988; Dodd 1989; Bailey and Guyer 1998; Holmes 2005). Males generally outnumber females, although there was a decline in the ratio of males to females from the 1980 s to the 2000s (Bailey and Guyer 1998; Holmes 2005). Flattened musk turtles are parasitized by leeches in inverse proportion to the degree of habitat degradation (Dodd 1988a).

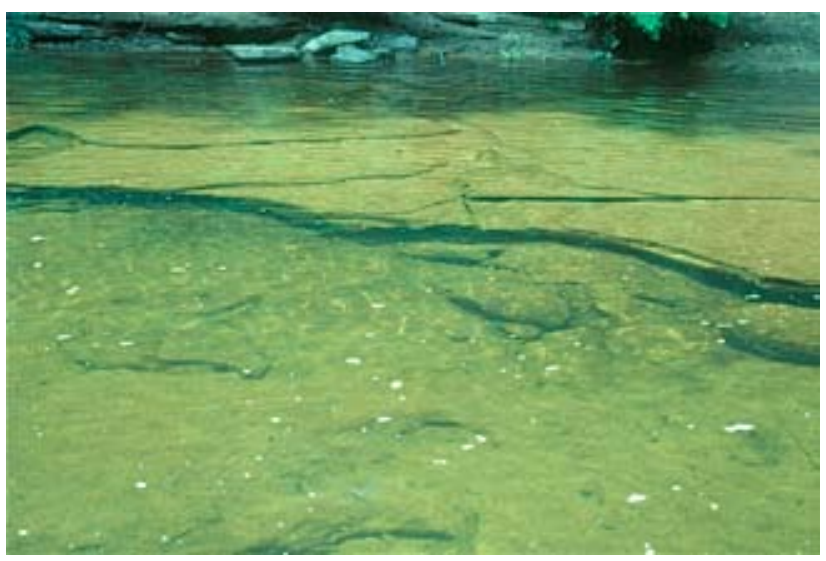

Figure 8. Sipsey Fork, Alabama. Ideal Sternotherus depressus habitat, showing sandstone crevice. Photo by C. Kenneth Dodd, Jr.

Population Status. - At one time, the turtle probably occurred in nearly all streams and rivers throughout the Warrior Basin above the Fall Line, but it is now confined to areas where pollution, sedimentation, and impoundments have not completely altered its habitat. Dodd (1990) estimated that only $6.9 \%$ of historically suitable habitat contained turtle populations unaffected by severe habitat degradation, $36.9 \%$ of the habitat had been severely degraded, and the remaining $56.3 \%$ of historically suitable habitat no longer contained viable $S$. depressus populations. In light of new information concerning the use of coves surrounding impoundments (Rogers and Marion 2004b; Holmes 2005), these figures are likely conservative.

There are few data on the status of this species prior to surveys conducted in the early to mid-1980s (Mount 1981; Ernst et al. 1983, 1989; Dodd et al. 1988). Population declines undoubtedly were severe because of extensive habitat degradation, as much of the turtle's range had been surface strip-mined for coal with few protective measures. Much additional habitat was lost as a result of impoundment (Dodd 1990), continuing erosion from unregulated coal strip mines (Alabama had no strip mine laws prior to 1969; Dodd et al. 1986), poor stream bank management, intensive forestry, urbanization, agriculture, highway construction, and municipal sewage and runoff. In addition, toxic chemical spills and other forms of pulse-related phenomena may have affected turtles and their prey populations.

Today, small isolated populations may be particularly vulnerable to habitat alteration or to stochastic or demographic "accidents" resulting from fragmentation (Dodd 1990). Examples of isolated or particularly small or vulnerable populations of S. depressus include those in Lost Creek and Gurley Creek. The extent to which cove populations are isolated also needs investigation. Additional surveys undoubtedly will refine knowledge of the turtle's microdistribution and identify other vulnerable populations. At least through the late 1990s, populations were still declining throughout the Warrior Basin, perhaps due to a continuing lack of recruitment and illegal take (Bailey and Guyer 1998). The results of recent surveys (Rogers and Marion 2004a; Holmes 2005) have suggested that populations are still viable at certain 
locations, and that populations were stable but at lower abundance than they had been in the mid-1980s. Holmes (2005) noted that trapping success may be related to water level and that environmental conditions need to be accounted for during trapping surveys.

Threats to Survival. - The flattened musk turtle is threatened primarily by habitat destruction and alteration and secondarily by collecting and possibly disease (Marion and Bailey 2004a). The turtle occupies crevices (Jackson 1988) and other cover sites that are easily covered by silt and sediment. Silt originates from a variety of sources within the Warrior Basin, including strip mines and improper stream-bank management during forestry, agricultural, and construction operations. In many areas adjacent to mines, coal fines (extremely fine particles of coal mixed with silt and sediment) clog stream bottoms to depths of one or more meters. Silt also eliminates cover sites and mollusk populations, the turtle's principal food, and may contain toxic chemicals or compounds. Sewage and pollution from nearby urban areas, especially the Birmingham metropolitan area, have drastically affected the biota of many streams in the Warrior Basin (U.S. Fish and Wildlife Service 1987).

Historically, collecting for the exotic turtle trade adversely affected certain populations of this species, although figures on the number of turtles removed are difficult to verify. Dodd et al. (1988) reported that as many as 200 turtles may have been illegally collected from Sipsey Fork in July 1985. Other reports of collecting involved turtles from Blackburn Fork and Blackwater Creek prior to federal protection, and sizeable collections were held by two private collectors (one in Georgia and the other in Alabama). Despite federal and state protection, reports of collecting in the Warrior Basin continued through the 1990s, as exemplified when flattened musk turtles were offered for sale by a herpetological dealer in Gainesville, Florida, in 1991. Individuals offering $S$. depressus for sale are still easy to locate on the internet (\$250 Canadian, 9 Feb 2008: http://www.pricenetwork.ca/ showthread.php?threadid $=167679 \& c s=1$ ). Local residents also may collect them as pets.

Mortality from a disease of unknown etiology, possibly in conjunction with collection by turtle enthusiasts, led to a precipitous decline in the Sipsey Fork population of $S$. depressus in 1985 (Dodd 1988b; Dodd et al. 1988). Even a very modest reduction in survivorship had serious consequences for the population (Fonnesbeck and Dodd 2003). The population size in 1986 was half the 1985 mid-year estimate. In addition to Sipsey Fork, a turtle with apparent disease symptoms also was found in Brushy Creek (Dodd 1988b). Turtles with disease symptoms were found prior to 1985 in Locust Fork (Mount 1981) and later in Lost Creek (Dodd 1990). Dodd (1988b) reported on bacteria and heavy metals in turtle tissues, but found no evidence for toxic poisoning. By 1995, the population at Sipsey Fork still had not recovered to pre-disease survey abundance (Bailey and Guyer 1998).

One of the most obvious symptoms of disease is shell necrosis resulting in eroded marginals and pits on the cara- pace and plastron. Extremely eroded shells occur in some populations of S. depressus (e.g., Blackburn Fork) but not in others (e.g., Blackwater Creek). Although speculative, erosion and pitting in certain populations may be indicative of past disease. Additional symptoms include emaciation, plastral lesions, carapace discoloration, swollen eyes, abnormal (light) facial coloration, and lack of leech parasites. Diseased turtles suffered from hypoproteinemia, and internal organs contained much edemic fluids and hemorrhagic and necrotic cells (Dodd 1988b). The immediate cause of death appeared to be pneumonia. Because of the multiplicity of symptoms and organs affected, E. Jacobson (pers. comm.) suggested that the turtles' immune systems had been compromised. The etiology of the disease and its long-term effects remain unknown. Disease may or may not continue to affect local populations, although Bailey and Guyer (1998) and Holmes (2005) found no obvious signs of the disease still affecting the Sipsey Fork population.

Conservation Measures Taken. - The flattened musk turtle is listed as follows - IUCN/SSC Specialist Group Action Plan Rating: 2; IUCN Red List: Vulnerable (http://www.iucnredlist.org); State law-Alabama: Protected; U.S.Endangered SpeciesAct of 1973: Threatened(U.S.Fish and Wildlife Service 1987), but with no critical habitat designation.

Both federal and state laws protect the flattened musk turtle from take. Turtle populations occur in Bankhead National Forest, including the Sipsey Wilderness Area, but no designated protected reserves include this species. In the 1980s, private individuals in Alabama and Georgia were rumored to have successfully bred $S$. depressus in captivity, but no details are available on methodology, results, or purpose of the breeding programs.

The U.S. Fish and Wildlife Service (Mount 1981; Dodd 1988b), Alabama Coal Association (Ernst et al. 1983, 1989), Office of Surface Mining of the U.S. Department of the Interior (Dodd et al. 1986, 1988), Birmingham Water Authority (Mount et al. 1991), and USDA Forest Service / The Nature Conservancy / Alabama Power Company (Rogers and Marion 2004a, 2004b; Holmes 2005) have sponsored surveys of the distribution and status of the flattened musk turtle. These surveys have documented the distribution of S. depressus over a $>20$-year period.

In the unpublished 1991 study, the Birmingham Water Authority funded surveys in LocustFork from the County Road 13 bridge near Shoal Creek Church, Blount County, to Hewitt Bridge west-southwest of Kimberly, Jefferson County. A total of 51 flattened musk turtles were trapped, but no juveniles or subadults were captured (Mount et al. 1991). Rogers and Marion (2004a) and Holmes (2005) also retrapped many sites for flattened musk turtles, but significant new populations have not been found except for those using coves around Lewis Smith Reservoir (Rogers and Marion 2004b).

A recovery plan for the turtle was approved by the U.S. Fish and Wildlife Service (1990) which advocated establishing a work group to address water quality problems, to monitor turtle populations and threats to them, and to implement protective measures that might be warranted. No funds were 
allocated to carry out this plan, and no working group was ever established. The recovery plan has never been updated, and the U.S. Fish and Wildlife Service (the primary federal agency responsible for carrying out provisions of the Endangered Species Act of 1973) has not sponsored or funded any conservation actions to date.

Conservation Measures Proposed. - Surveys have demonstrated that flattened musk turtles are found in a variety of stream habitats within the Warrior Basin. However, the upstream limits of distribution have yet to be established. Research has been conducted on habitat use in the upper reaches of Lewis Smith Reservoir, but much remains to be learned about turtle populations there. For example, these populations appear to be skewed toward larger individuals, but whether this represents an actual trend or a sampling bias remains to be determined. Nothing is known concerning the species' biology in larger rivers, such as Locust Fork. Although Dodd et al. (1988) followed 13 turtles in Sipsey Fork, the number of locations per turtle was generally few and the data were thus preliminary. Telemetry should be used to follow turtles in different habitat conditions, such as small streams (e.g., Lost Creek), intermediate-sized streams (e.g., upper West Sipsey Fork), and large streams or rivers (e.g.,Locust Fork).Moreover, habitat use could be examined under different stream conditions, such as in non-impacted versus heavily silted sites. By following turtles during different seasons, nesting and overwintering sites could be identified.

Populations previously affected by disease (West Sipsey Fork, Lost Creek) should be monitored periodically to determine the population status. If diseased turtles are found, research should focus on etiology, including the lethal and sublethal effects of toxic substances (insecticides, herbicides, heavy metals, organochlorines, PCBs) on turtles and their molluscan prey. Tissues from diseased turtles should be cultured for viruses. A better understanding of parasites and their role, if any, in disease transmission would be desirable.

Ernst et al. (1983, 1989), Dodd et al. (1986, 1988), Johnson (1986), Dodd (1988b), Bailey and Guyer (1998), Rogers and Marion (2004a), and Holmes (2005) trapped and marked flattened musk turtles at sites common to their projects. These studies provided baseline data on population size, structure, and status. Continuing to monitor populations initially sampled from the mid-1980s to early 2000s could provide long-term comparisons and yield data on growth, survivorship, and effects of habitat disturbance. Study sites in Sipsey Fork, Brushy Creek, Lost Creek, Blackburn Fork, and Blackwater Creek should be periodically re-censused.

In light of the above, research should: 1) continue to refine knowledge of the distribution of the turtle throughout the Warrior Basin, particularly headwater streams; 2) focus on telemetry studies of habitat use to establish the extent of occupation and travel within impoundments and large rivers; 3) establish long-term studies on demography to include reproduction, recruitment, population growth rates, survivorship and effects of perturbations at a variety of loca- tions; and 4) conduct studies on gastropod prey populations and how they are being affected by habitat alteration.

Marion and Bailey (2004b) recommended that: 1) local efforts to restore stream quality in the Warrior Basin should be undertaken; 2) laws and regulations relating to water quality and mining should be strengthened and enforced; 3) populations should be monitored; 4) contaminant studies should be carried out on turtles and sediments; 5) genetic studies should ascertain the effects of habitat fragmentation of flattened musk turtle populations; and 6) studies need to be conducted on habitat use in reservoirs. In addition to these general recommendations, it is important to promote an understanding of the importance of biodiversity, endangered species management, and the uniqueness of Alabama's natural heritage to local residents and county government officials.

Captive Husbandry. - The turtle has been kept by private collectors in Alabama and Georgia, but no details are available on captive husbandry. Musk and mud turtles generally do well when held as captives by experienced people.

Current Research. - As of May 2008 there are apparently no specific research or recovery projects underway on the biology or conservation of the flattened musk turtle (J. Godwin, Alabama Natural Heritage Program; P. Hartfield, U.S. Fish and Wildlife Service; A. Cochran, USDA Forest Service, pers. comm.). Ken Marion (University of Alabama-Birmingham, pers. comm.) is in the process of preparing manuscripts on the results of his and his students' research.

Acknowledgments. - I thank Allison Cochran, Jim Godwin, Craig Guyer, Ken Marion, and Paul Hartfield for supplying references and information on the current status of the flattened musk turtle. Marian Griffey offered suggestions for improving the manuscript.

\section{LITERATURE CITED}

Bailey, K.A. And GuYer, C. 1998. Demography and population status of the flattened musk turtle, Sternotherus depressus, in the Black Warrior River Basin of Alabama. Chelonian Conservation and Biology 3:77-83.

Bonin, F., Devaux, B. and Dupré,A. 2006. Turtles of the World. Johns Hopkins University Press, Baltimore, Maryland, USA.

Close, D.K. 1982. The reproductive cycle of Sternotherus minor depressus. M.S. Thesis, University of Alabama-Birmingham, Birmingham, Alabama.

DoDD, C.K., JR. 1988a. Patterns of distribution and seasonal use of the turtle Sternotherus depressus by the leech Placobdella parasitica. Journal of Herpetology 22:74-81.

DoDD,C.K.,JR. 1988b. Disease and population declines in the flattened musk turtle Sternotherus depressus. American Midland Naturalist 119:394-401.

DoDD, C.K., JR. 1989. Secondary sex ratio variation in populations of the flattened musk turtle, Sternotherus depressus. Copeia 1989:1041-1045.

DoDD, C.K., JR. 1990. Effects of habitat fragmentation on a streamdwelling species, the flattened musk turtle Sternotherus depressus. Biological Conservation 54:33-45.

Dodd, C.K., JR., EnGe, K.M. And Stuart, J.N. 1986. The effects of 
mining siltation on the distribution and abundance of the flattened musk turtle, Sternotherus depressus, in northern Alabama. Report to the Office of Surface Mining, Washington, D.C.

DodD, C.K., JR., Enge, K.M. And StUART, J.N. 1988. Aspects of the biology of the flattened musk turtle (Sternotherus depressus) in northern Alabama. Bulletin of the Florida State Museum, Biological Sciences 34:1-64.

ERnst, C.H. AND Barbour, R.W. 1989. Turtles of the World. Smithsonian Institution Press, Washington, D.C., 313 pp.

ERnst, C.H., Cox, W.A. and Marion, K.R. 1983. The distribution and status of the flattened musk turtle in the Warrior Basin of Alabama. Report to the Alabama Coal Association, Birmingham, Alabama.

ERnst, C.H., Cox, W.A. AND Marion, K.R. 1989. The distribution and status of the flattened musk turtle, Sternotherus depressus (Testudines, Kinosternidae). Tulane Studies in Zoology and Botany 27:1-20.

ERnst, C.H., Lovich, J.E., AND Barbour, R.W. 1994. Turtles of the United States and Canada. Smithsonian Institution Press, Washington, DC, $578 \mathrm{pp}$.

EstRIDGE, R.E. 1970. The taxonomic status of Sternotherus depressus (Testudinata, Kinosternidae) with observations on its ecology.M.S. Thesis, Auburn University, Auburn, Alabama.

FonNesBeck, C. J. AND DodD, JR., C.K. 2003. Estimation of flattened musk turtle (Sternotherus depressus) survival, recapture, and recovery rate during and after a disease outbreak. Journal of Herpetology 37:602-607.

FRITZ, U. AND HaVAš, P. 2007. Checklist of chelonians of the world. Vertebrate Zoology 57:149-368.

HoLmES,S.R. 2005.The status of the flattened musk turtle,Sternotherus depressus, in the William B. Bankhead National Forest and Lewis Smith Reservoir, with emphasis on aspects of growth, demography, and the effects of habitat conditions on apparent population size. M.S. Thesis, University of Alabama-Birmingham, Birmingham, Alabama.

Iverson, J.B. 1977a. Geographic variation in the musk turtle Sternotherus minor. Copeia 1977:502-517.

Iverson, J.B. 1977b. Sternotherus depressus Tinkle and Webb. Catalogue of American Amphibians and Reptiles 194.1-2.

JACKSON,J.F. 1988.Crevice occupation by musk turtles: taxonomic distribution and crevice attributes. Animal Behaviour 36:793-801.

JoHNSON,A.R. 1986.An investigation of habitat parameters influencing population sizes of flattened musk turtle, Sternotherus depressus, with observations on aspects of behavior. M.S. Thesis, University of Alabama-Birmingham, Birmingham, Alabama.

Marion, K.R. and BaILey, M. 2004a. Flattened musk turtle. Sternotherus depressus Tinkle and Webb. In: Mirarchi, R.E., Bailey, M.A., Garner, J.T., Haggerty, T.M., Best, T.L., Mettee M.F. and O’Neill,P.(Eds.).Alabama Wildlife. Volume 3.Imperiled Amphibians, Reptiles, Birds, and Mammals. University of Alabama Press, Tuscaloosa, Alabama, pp. 80-81.

Marion, K.R. and BaILEY, M. 2004b. Flattened musk turtle. Sternotherus depressus Tinkle and Webb. In: Mirarchi, R.E., Bailey, M.A., Garner, J.T., Haggerty, T.M., Best, T.L., Mettee, M.F. and O'Neill, P. (Eds.). Alabama Wildlife. Volume 4. Conservation and Management Recommendations for Imperiled Wildlife, University of Alabama Press, Tuscaloosa, Alabama,p. 172.

Marion, K.R., ERnSt, C.H. AND Cox, W.A. 1984. A xanthic flattened musk turtle, Sternotherus depressus. Herpetological Review 15:51

Marion, K.R., Cox, W.A. And ERnst, C.H. 1991. Prey of the flattened musk turtle, Sternotherus depressus. Journal of Herpetology 25:385-387.

Mount, R.H. 1975. The Reptiles and Amphibians of Alabama. Agriculture Experiment Station, Auburn University, Auburn, Alabama, 347 pp.

MounT,R.H.1981.The status of the flattened musk turtle,Sternotherus minor depressus Tinkle and Webb. Report to the U.S. Fish and Wildlife Service, Jackson, Mississippi.

Mount, R.H., Marion, K.R. AND Cox, W.A. 1991. Status of the flattened musk turtle, Sternotherus depressus, in the mid-reaches of the Locust Fork of the Black Warrior River, Blount and Jefferson counties, Alabama. Report to Water Works and Sewer Board of the City of Birmingham, Alabama.

RoGERS,S.R.H. AND MARION,K.R.2004a.Assessment of the suitability of selected stream sites in Bankhead National Forest for occupation by populations of flattened musk turtles (Sternotherus depressus), and the potential effects of silvicultural improvements on habitat quality. Report submitted to the U.S.D.A. Forest Service, Alabama Power Company, and The Nature Conservancy of Alabama.

Rogers, S.R.H. AND MARION, K.R. 2004b. Assessment of the population status of the flattened musk turtle (Sternotherus depressus) in the Sipsey Fork and Brushy Creek branches of Lewis Smith Lake, Alabama. Report to Alabama Power Company, U.S.D.A. Forest Service, and The Nature Conservancy of Alabama.

SCHNUELLE, K.A. 1997. Demography, diet and prey availability of the flattened musk turtle, Sternotherus depressus. M.S.Thesis, Auburn University, Auburn, Alabama.

SEIDEL, M.E. AND LuCCHINo, R.V. 1981. Allozymic and morphological variation among the musk turtles Sternotherus carinatus, S. depressus, and S. minor (Kinosternidae). Copeia 1981:119-128.

SEIDEL, M.E., ReYNolds, S.L. AND Lucchino, R.V. 1981. Phylogenetic relationships among musk turtles (genus Sternotherus) and genetic variation in Sternotherus odoratus. Herpetologica 37:161-165.

SEIDEL,M.E.,Iverson,J.B. ANDAdKINS,M.D. 1986.Biochemical comparisons and phylogenetic relationships in the family Kinosternidae (Testudines). Copeia 1986:285-294.

TinkLE, D.W. 1958. The systematics and ecology of the Sternotherus carinatus complex (Testudinata, Chelydridae). Tulane Studies in Zoology 6:3-56.

TINKLE, D.W. 1959. The relation of the Fall Line to the distribution and abundance of turtles. Copeia 1959:167-170.

TinkLE, D.W. 1962. Variation in shell morphology of North American turtles. I. The carapacial seam arrangement. Tulane Studies in Zoology 9:331-349.

TinkLe, D.W. AND WeBB, R.G. 1955. A new species of Sternotherus with a discussion of the Sternotherus carinatus complex (Chelonia, Kinosternidae). Tulane Studies in Zoology 3:52-67.

U.S. Fish and WildLIFE Service. 1987. Determination of threatened status for the flattened musk turtle (Sternotherus depressus).Federal Register 50(212):45638- 45643.

U.S. Fish and Wildlife Service. 1990. Flattened musk turtle (Sternotherus depressus) recovery plan. U.S. Fish and Wildlife Service, Jackson, Mississippi.

WALKER,D. ANDAVISE,J.C. 1998.Principles of phylogeography asillustrated by freshwater and terrestrial turtles in the southeastern United States. Annual Review of Ecology and Systematics 29:23-58.

WALKER,D.,OrTí,G.,ANDAvISE,J.C.1998.Phylogenetic distinctiveness of athreatened aquatic turtle(Sternotherusdepressus).Conservation Biology 12:639- 645.

Wermuth, H. and Mertens, R. 1961. Schildkröten, Krokodile, Bruckeneschen. G. Fischer, Jena, 422 pp.

\section{Citation Format for this Account:}

DodD, C.K., JR. 2008. Sternotherus depressus Tinkle and Webb 1955 - flattened musk turtle. In: Rhodin, A.G.J., Pritchard, P.C.H., van Dijk, P.P., Saumure, R.A., Buhlmann, K.A., and Iverson, J.B. (Eds.). Conservation Biology of Freshwater Turtles and Tortoises: A Compilation Project of the IUCN/SSC Tortoise and Freshwater Turtle Specialist Group. Chelonian Research Monographs No. 5, pp.013.1-013.7, doi:10.3854/crm.5.013.depressus.v1.2008, http:// www.iucn-tftsg.org/cbftt/. 